\title{
Analysis of the methane-bearing capacity in Polish hard coal mines in the years 1993-2018
}

\author{
Magdalena Tutak $^{1 *}$ \\ ${ }^{1}$ Silesian University of Technology, Faculty of Mining, Safety Engineering and Industrial \\ Automation, Akademicka 2A, 44-100 Gliwice, Poland
}

\begin{abstract}
The process of underground coal production is inseparably connected with methane emissions. This gas has good energy characteristics and, at the same time, represents a huge threat to the safety of mining exploitation. Due to its flammability and explosiveness, the occurrence of methane-related incidents disturbs the entire production process and is extremely dangerous for the crew. Moreover, methane is a greenhouse gas that has a highly negative impact on the natural environment. These factors make it necessary to carry out works in order to limit its negative effects and increase its use as an energy raw material. The article presents the results of an analysis of the main parameters describing the methane-bearing capacity in Polish hard coal mines. The analysis was conducted within the scope of their absolute values and with reference to one tonne of coal extracted. The purpose of these studies was to identify the changes in the parameters under analysis over the last 25 years in the Polish mining industry and, at the same time, to determine how the structural changes in the mining industry and the entire economy influenced those parameters. This particularly concerns the emission of methane into the environment. The reason is that this value has a huge influence on the opinion about the mining industry. The results presented should be used for works on limiting the harmful effects of methane and increasing the degree of its utilisation in the economy.
\end{abstract}

\section{Introduction}

One of the basic hazards that are commonly faced by underground hard coal mines is the methane hazard [1-16]. This hazard is associated with the emission of methane into underground mine headings during coal exploitation. In coal deposits, methane is present in two fundamental forms: as sorbed methane, which is physicochemically bound with a carbon substance, and as free methane, occurring in pores and crevices of gangues and coal $[15,16]$. Methane is odourless and colourless, and lighter than air (its density is 0.656 $\mathrm{kg} / \mathrm{m}^{3}$ ). When its concentration level in the air ranges between $5 \%$ and $15 \%$, it becomes explosive (in mixture with the air in which oxygen concentration is at least $12 \%$ ) and hence extremely dangerous. Therefore, due to its flammability and explosiveness, methane is an extremely dangerous gas. It represents a threat for miners and the entire process of mining

\footnotetext{
*Corresponding author: Magdalena.tutak@polsl.pl
} 
exploitation. Additionally, it is one of the most harmful greenhouse gases. When emitted into the atmosphere, it can stay there from 9 to 15 years [17].

Hence, it can be concluded that methane poses a serious threat to the safety and effectiveness of mining production, as well as negatively affects the natural environment. On the other hand, methane is a high-energy gas. As an energy raw material, it is classified under low-carbon energy sources. Therefore, the process of methane drainage (demethylation) is becoming increasingly common in underground mines. It involves the recovery of methane from the seams of as-yet-unmined coal. Unfortunately, this process is capable of recovering only a part of the methane present in the coal seam. The remaining part enters the mine headings and, when specific conditions are met, may represent a huge threat.

Polish hard coal mines have a high methane-bearing capacity. The unit content of methane in coal seams currently reaches up to a few dozen cubic metres calculated per tonne of coal extracted $\left(\mathrm{m}^{3} \mathrm{CH}_{4} / \mathrm{t}\right)$. Since the end of the $1990 \mathrm{~s}$, the quantity of coal extracted in Poland has been systematically decreasing. In 1993, around 130 million tonnes of coal were extracted in Poland, while in 2018, it was only 63.38 million tonnes, representing over a two-fold decrease in extraction. At the same time, the methane-bearing capacity of Polish mines has increased over this period from 773.3 million $\mathrm{m}^{3}$ to 916.05 million $\mathrm{m}^{3}$ of methane [18]. This means that the exploitation process has been moved to seams with increasing methane content. Between 1993 and 2018, the quantity of methane captured via methane drainage systems increased from 212.8 to 317 million $\mathrm{m}^{3}$ [18].

Methane released into mine headings constitutes one of the most serious natural hazards in Polish hard coal mines. Each year, these mines experience a number of dangerous incidents related to methane. Methane combustion may lead to explosions or fires $[1,19$, 20]. Dangerous methane-related incidents also represent a huge threat to the crew working in the headings, as well as to the continuity of the production process [21].

From the perspective of the transformations that have recently taken place in the Polish mining industry, an extremely interesting issue is the analysis of the parameters that define the methane-bearing capacity of this sector. This is because the results of such an analysis allow for assessing those transformations and developing recommendations for future actions in order to limit the negative effects of methane emissions and utilise its energy potential.

The article presents an analysis of the basic parameters related to methane emissions in Polish hard coal mines in the years 1993-2018. To a great extent, this analysis encompassed total methane emissions, ventilation methane-bearing capacity, methane quantities obtained from methane drainage systems, as well as the percentage of those quantities utilised and emitted into the atmosphere.

These parameters were also referred to the quantity of coal extracted, thereby determining their relative values. Within the context of the climate policy pursued, the quantity of methane emitted into the natural environment is a very significant parameter. This parameter is highly unfavourable as far as mining exploitation is concerned.

The parameters in question were also subjected to a correlation analysis. Correlation matrices were determined between the values under analysis and a normality test for their distributions was carried out. The results obtained are presented in the paper.

\section{Materials and method}

The analysis was based on statistical data concerning the methane-bearing capacity of Polish hard coal mines, included in the report on the basic natural and technical hazards in hard coal mining [18] and the publications by the State Mining Authority [22]. The data 
concerning methane emissions from Polish hard coal mines in the years 1993-2018 are presented in Table 1.

Table 1. Data concerning methane emissions from Polish hard coal mines in the years 1993-2018.

\begin{tabular}{|c|c|c|c|c|c|c|}
\hline Year & $\begin{array}{c}\text { Coal } \\
\text { production, } \\
\text { million ton }\end{array}$ & $\begin{array}{l}\text { Absolute } \\
\text { methane } \\
\text { content, } \\
\text { million } \mathbf{m}^{3}\end{array}$ & $\begin{array}{c}\text { Methane } \\
\text { content in } \\
\text { ventilation } \\
\text { air, million } \\
\text { m }^{3}\end{array}$ & $\begin{array}{l}\text { Methane } \\
\text { drainage, } \\
\text { million } \mathbf{m}^{3}\end{array}$ & $\begin{array}{l}\text { The use of } \\
\text { methane, } \\
\text { million } \mathbf{m}^{3}\end{array}$ & $\begin{array}{c}\text { Methane } \\
\text { emissions to the } \\
\text { atmosphere from } \\
\text { drainage } \\
\text { systems, million } \\
\text { m }^{3} \\
\end{array}$ \\
\hline 1993 & 130.0 & 773.3 & 560.5 & 212.8 & 167.6 & 45.2 \\
\hline 1994 & 132.3 & 762.0 & 560.8 & 201.2 & 136.3 & 64.9 \\
\hline 1995 & 135.2 & 748.0 & 550.5 & 197.5 & 137.1 & 60.4 \\
\hline 1996 & 136.0 & 748.4 & 555.9 & 192.5 & 147.5 & 45 \\
\hline 1997 & 137.1 & 748.4 & 555.9 & 192.5 & 134.4 & 58.1 \\
\hline 1998 & 115.9 & 763.3 & 559.7 & 203.6 & 152.7 & 50.9 \\
\hline 1999 & 110.4 & 744.5 & 528.4 & 216.1 & 136.9 & 79.2 \\
\hline 2000 & 102.5 & 746.9 & 530.8 & 216.1 & 124.0 & 92.1 \\
\hline 2001 & 102.6 & 743.7 & 529.4 & 214.3 & 131.5 & 82.8 \\
\hline 2002 & 102.1 & 752.6 & 545.3 & 207.3 & 122.4 & 84.9 \\
\hline 2003 & 100.4 & 798.1 & 571.0 & 227.1 & 127.8 & 99.3 \\
\hline 2004 & 99.5 & 825.9 & 575.0 & 250.9 & 144.5 & 106.4 \\
\hline 2005 & 98.1 & 851.1 & 595.8 & 255.3 & 144.8 & 110.5 \\
\hline 2006 & 95.4 & 870.3 & 580.8 & 289.5 & 158.3 & 131.2 \\
\hline 2007 & 87.4 & 878.9 & 610.1 & 268.8 & 165.7 & 103.1 \\
\hline 2008 & 83.6 & 880.9 & 606.7 & 274.2 & 156.5 & 117.7 \\
\hline 2009 & 77.4 & 855.7 & 595.9 & 259.8 & 159.5 & 100.3 \\
\hline 2010 & 76.1 & 834.9 & 579.0 & 255.9 & 161.1 & 94.8 \\
\hline 2011 & 75.5 & 828.8 & 578.6 & 250.2 & 166.3 & 83.9 \\
\hline 2012 & 79.2 & 828.2 & 561.5 & 266.7 & 178.6 & 88.1 \\
\hline 2013 & 76.5 & 847.8 & 571.2 & 276.6 & 187.7 & 88.9 \\
\hline 2014 & 72.5 & 891.2 & 570.1 & 321.1 & 211.4 & 109.7 \\
\hline 2015 & 72.2 & 933.0 & 594.0 & 339 & 197.1 & 141.9 \\
\hline 2016 & 70.4 & 933.8 & 591.7 & 342.1 & 195.0 & 147.1 \\
\hline 2017 & 65.5 & 948.5 & 611.5 & 337.0 & 212.0 & 125 \\
\hline 2018 & 63.4 & 916.1 & 599.1 & 317.0 & 203.1 & 113.9 \\
\hline
\end{tabular}

The data summarised in Table 1 served as the basis for determining the following indicators for describing the methane balance of Polish mines:

- Coal output (million $\mathrm{t}$ ),

- Total (absolute) methane emissions $\left(\right.$ million $\left.\mathrm{m}^{3}\right)$,

- Methane content in ventilation air (million $\left.\mathrm{m}^{3}\right)$,

- Methane drainage (million $\left.\mathrm{m}^{3}\right)$,

- The use of methane (million $\mathrm{m}^{3}$ ),

- Methane emissions to the atmosphere from drainage systems (million $\mathrm{m}^{3}$ ).

These data were also used for identifying the total quantity of methane emitted from mining production into the natural environment (Fig. 1). 


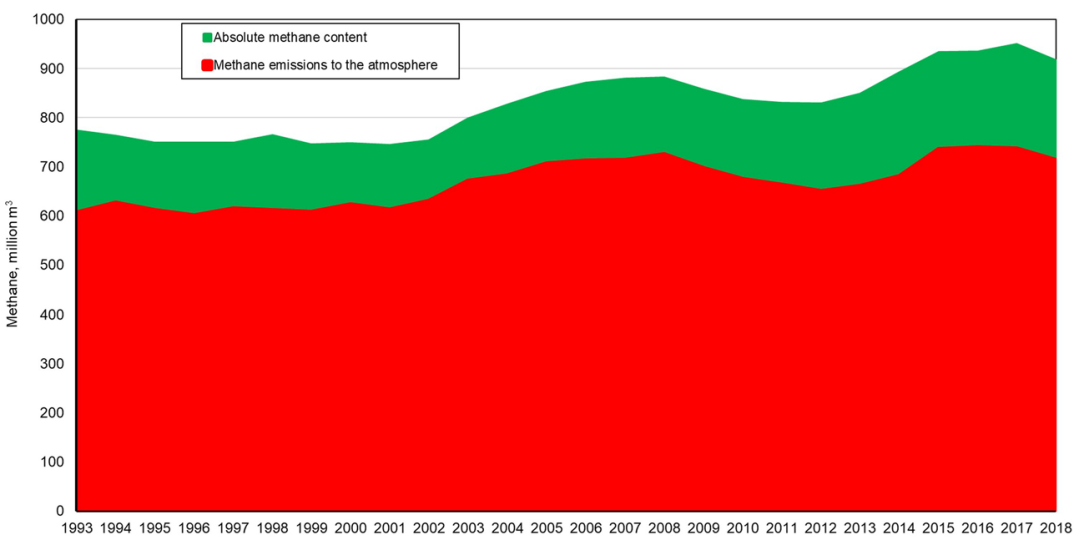

Fig. 1. Total quantity of methane emitted from mining production into the natural environment.

Table 2. Data concerning methane emissions from Polish hard coal mines in the years 1993-2018 per tonne of coal extracted.

\begin{tabular}{|c|c|c|c|c|c|}
\hline Year & $\begin{array}{c}\text { Absolute } \\
\text { methane } \\
\text { content, million } \\
\text { m }^{3}\end{array}$ & $\begin{array}{c}\text { Methane } \\
\text { content in } \\
\text { ventilation air, } \\
\text { million } \mathbf{~ m}^{3}\end{array}$ & $\begin{array}{l}\text { Methane } \\
\text { drainage, } \\
\text { million } \mathbf{m}^{3}\end{array}$ & $\begin{array}{l}\text { The use of } \\
\text { methane, } \\
\text { million } \mathbf{m}^{3}\end{array}$ & $\begin{array}{l}\text { Methane emissions } \\
\text { to the atmosphere } \\
\text { from drainage } \\
\text { systems, million } \mathrm{m}^{3}\end{array}$ \\
\hline 1993 & 5.95 & 4.31 & 1.64 & 1.29 & 0.35 \\
\hline 1994 & 5.76 & 4.24 & 1.52 & 1.03 & 0.49 \\
\hline 1995 & 5.53 & 4.07 & 1.46 & 1.01 & 0.45 \\
\hline 1996 & 5.50 & 4.09 & 1.42 & 1.08 & 0.33 \\
\hline 1997 & 5.46 & 4.05 & 1.40 & 0.98 & 0.42 \\
\hline 1998 & 6.59 & 4.83 & 1.76 & 1.32 & 0.44 \\
\hline 1999 & 6.74 & 4.79 & 1.96 & 1.24 & 0.72 \\
\hline 2000 & 7.29 & 5.18 & 2.11 & 1.21 & 0.90 \\
\hline 2001 & 7.25 & 5.16 & 2.09 & 1.28 & 0.81 \\
\hline 2002 & 7.37 & 5.34 & 2.03 & 1.20 & 0.83 \\
\hline 2003 & 7.95 & 5.69 & 2.26 & 1.27 & 0.99 \\
\hline 2004 & 8.30 & 5.78 & 2.52 & 1.45 & 1.07 \\
\hline 2005 & 8.68 & 6.07 & 2.60 & 1.48 & 1.13 \\
\hline 2006 & 9.12 & 6.09 & 3.03 & 1.66 & 1.38 \\
\hline 2007 & 10.06 & 6.98 & 3.08 & 1.90 & 1.18 \\
\hline 2008 & 10.54 & 7.26 & 3.28 & 1.87 & 1.41 \\
\hline 2009 & 11.06 & 7.70 & 3.36 & 2.06 & 1.30 \\
\hline 2010 & 10.97 & 7.61 & 3.36 & 2.12 & 1.25 \\
\hline 2011 & 10.98 & 7.66 & 3.31 & 2.20 & 1.11 \\
\hline 2012 & 10.46 & 7.09 & 3.37 & 2.26 & 1.11 \\
\hline 2013 & 11.08 & 7.47 & 3.62 & 2.45 & 1.16 \\
\hline 2014 & 12.29 & 7.86 & 4.43 & 2.92 & 1.51 \\
\hline 2015 & 12.92 & 8.23 & 4.70 & 2.73 & 1.97 \\
\hline 2016 & 13.26 & 8.40 & 4.86 & 2.77 & 2.09 \\
\hline 2017 & 14.48 & 9.34 & 5.15 & 3.24 & 1.91 \\
\hline 2018 & 14.45 & 9.45 & 5.00 & 3.20 & 1.80 \\
\hline
\end{tabular}

While analysing the results obtained, one can conclude that methane emission into the natural environment calculated per tonne of coal extracted has been on a significant increase in recent years. This results from the growing methane-bearing capacity of the seams under exploitation. 
A statistical analysis was performed for the data presented in Tables 1 and 2. It was based on the Pearson correlation coefficients between the studied variables and the correlation matrix between these coefficients. The results are summarized in Tables 3 and 4 respectively.

The Pearson correlation coefficients were calculated from the relationship:

$$
r_{X Y}=\frac{\operatorname{cov}(X, Y)}{\sigma_{x} \sigma_{Y}}=\frac{\left(\sum_{i=1}^{n} \sum_{j=1}^{m} P\left(X=x_{i}, Y=y_{i}\right) x_{i} y_{j}\right)-\overline{X Y}}{\sqrt{\left(\sum_{i=1}^{n} P\left(X=x_{i}\right) x_{i}^{2}\right)-X^{2} \sqrt{\left(\sum_{i=1}^{m} P\left(Y=y_{i}\right) y_{i}^{2}\right)-Y^{2}}}}
$$

The analysis was conducted for both absolute and relative data (with reference to one tonne of coal extracted).

\section{Research results}

It primary purpose was to determine the relationships between the values analysed and their reference to the volume of coal extraction. For both sets of data, the values of the correlation coefficients between the variables were determined for the level of statistical significance equal to $\mathrm{p}<0.05$.

The value of the correlation coefficients determined for the absolute values of the analysed parameters of methane emissions is presented in Table 3. Table 4, on the other hand, presents the values of the correlation coefficients between the parameters defining methane emissions, referred to the volume of coal extracted.

Table 3. Summary of the values of the correlation coefficients between the parameters defining methane emissions in hard coal mines.

\begin{tabular}{|c|c|c|c|c|c|c|}
\hline & $\begin{array}{c}\text { Coal } \\
\text { production }\end{array}$ & $\begin{array}{c}\text { Absolute } \\
\text { methane } \\
\text { content }\end{array}$ & $\begin{array}{c}\text { Methane } \\
\text { content in } \\
\text { ventilation } \\
\text { air }\end{array}$ & $\begin{array}{c}\text { Methane } \\
\text { drainage }\end{array}$ & $\begin{array}{c}\text { The use } \\
\text { of } \\
\text { methane }\end{array}$ & $\begin{array}{c}\text { Methane } \\
\text { emissions } \\
\text { from } \\
\text { drainage } \\
\text { systems }\end{array}$ \\
\hline $\begin{array}{c}\text { Coal } \\
\text { production }\end{array}$ & 1.00 & -0.84 & -0.62 & -0.86 & -0.71 & -0.80 \\
\hline $\begin{array}{c}\text { Absolute } \\
\text { methane } \\
\text { content }\end{array}$ & -0.84 & 1.00 & 0.87 & 0.97 & 0.84 & 0.85 \\
\hline $\begin{array}{c}\text { Methane } \\
\text { content in } \\
\text { ventilation air }\end{array}$ & -0.62 & 0.87 & 1.00 & 0.72 & 0.62 & 0.64 \\
\hline $\begin{array}{c}\text { methane } \\
\text { drainage }\end{array}$ & -0.86 & 0.97 & 0.72 & 1.00 & 0.87 & 0.87 \\
\hline $\begin{array}{c}\text { The use of } \\
\text { methane }\end{array}$ & -0.71 & 0.84 & 0.62 & 0.87 & 1.00 & 0.52 \\
\hline $\begin{array}{c}\text { Methane } \\
\text { emissions } \\
\text { from drainage } \\
\text { systems }\end{array}$ & -0.80 & 0.85 & 0.64 & 0.87 & 0.52 & 1.00 \\
\hline
\end{tabular}


Table 4. Summary of the values of the correlation coefficients between the parameters defining methane emissions, referred to the volume of coal extracted.

\begin{tabular}{|c|c|c|c|c|c|}
\hline & $\begin{array}{c}\text { Absolute } \\
\text { methane } \\
\text { content }\end{array}$ & $\begin{array}{c}\text { Methane } \\
\text { content in } \\
\text { ventilation air }\end{array}$ & $\begin{array}{c}\text { Methane } \\
\text { drainage }\end{array}$ & $\begin{array}{c}\text { The use of } \\
\text { methane }\end{array}$ & $\begin{array}{c}\text { Methane } \\
\text { emissions from } \\
\text { drainage systems }\end{array}$ \\
\hline $\begin{array}{c}\text { Absolute } \\
\text { methane } \\
\text { content }\end{array}$ & 1.00 & 1.00 & 0.99 & 0.97 & 0.95 \\
\hline $\begin{array}{c}\text { Methane } \\
\text { content in } \\
\text { ventilation air }\end{array}$ & 1.00 & 1.00 & 0.97 & 0.96 & 0.93 \\
\hline $\begin{array}{c}\text { methane } \\
\text { drainage }\end{array}$ & 0.99 & 0.97 & 1.00 & 0.98 & 0.96 \\
\hline $\begin{array}{c}\text { The use of } \\
\text { methane }\end{array}$ & 0.97 & 0.96 & 0.98 & 1.00 & 0.88 \\
\hline $\begin{array}{c}\text { Methane } \\
\text { emissions from } \\
\text { drainage } \\
\text { systems }\end{array}$ & 0.95 & 0.93 & 0.96 & 0.88 & 1.00 \\
\hline
\end{tabular}

The analysis of the results obtained demonstrated that the variables under investigation show different values of the correlation coefficient (Tables 3 and 4). Table 3 shows considerable differences in the values of these coefficients. On the other hand, when calculated per tonne of coal extracted, these values are very close to each other and demonstrate a high level of correlation (Table 4).

In the case of the variables from Table 3, the highest positive value of the correlation coefficient can be found between the total and the ventilation methane-bearing capacities (0.97), as well as between the total and the ventilation methane-bearing capacities, methane drainage and methane utilisation (0.87). On the other hand, the lowest positive value of this coefficient occurs between the utilisation of methane (captured via drainage systems) and its emission from the drainage system into the atmosphere (0.52).

On the other hand, the analysis of the correlation coefficient for the variables from Table 4 revealed that the highest positive value of the correlation coefficient can be found between the total methane-bearing capacity and methane drainage, amounting to 0.99 . The lowest positive value of this coefficient occurs between the utilisation of methane (captured via drainage systems) and its emission from the drainage system into the atmosphere, and is equal to 0.88 .

Additionally, an analysis was performed for the distributions of the variables under analysis. The results obtained indicate that they are characterised by normal distribution. The normality distribution assessment of the variables was carried out using the Kolmogorov-Smirnov (K-S) test with Lilliefors significance correction. This test was used due to the small number of data describing the variable $(<30)$.

Figure 2 presents sample distributions of the absolute values for the variables under analysis, whereas Figure 3 shows the distributions for values calculated per tonne of coal extracted. 

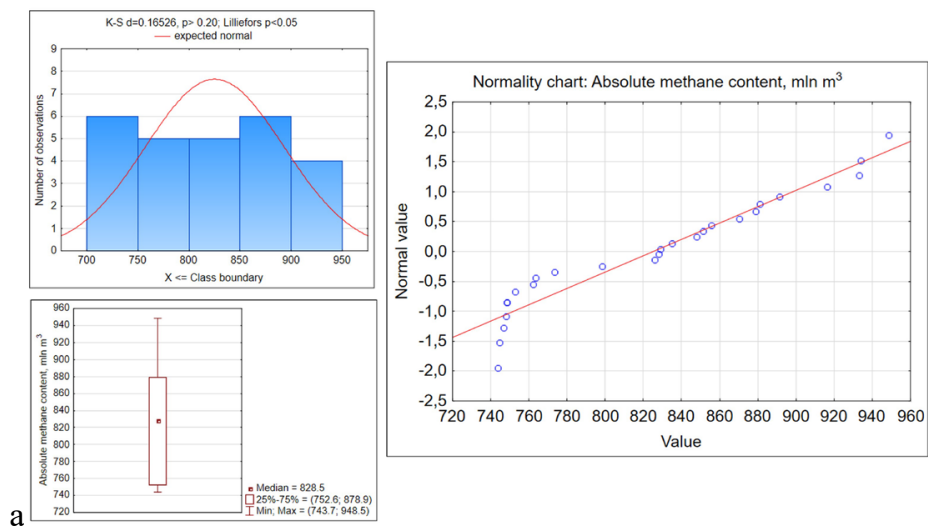

a
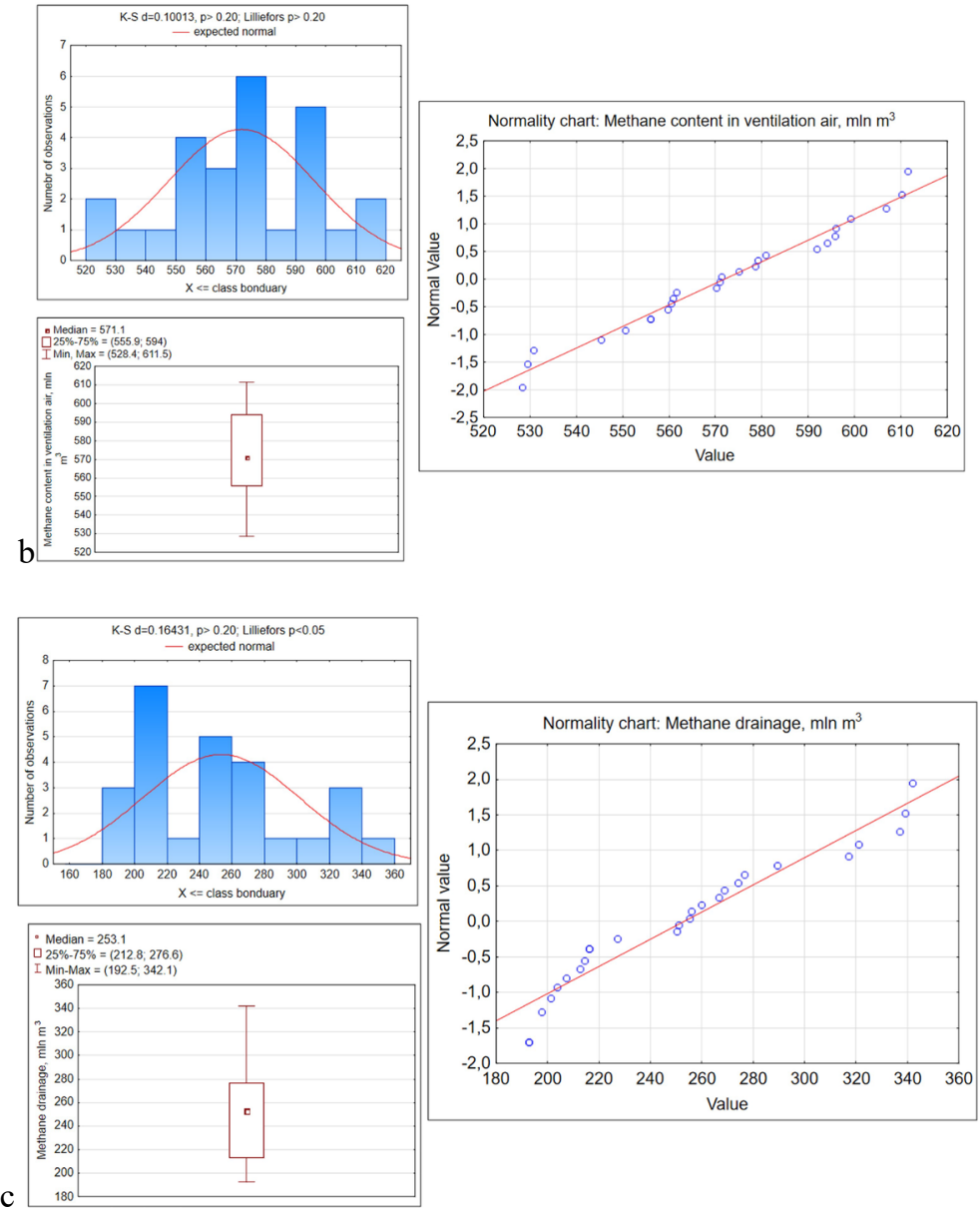

Fig. 2. Distributions of the absolute values for the variables under analysis (a-absolute methane content, $\mathrm{b}$-methane content in ventilation air, $\mathrm{c}$ - methane drainage). 

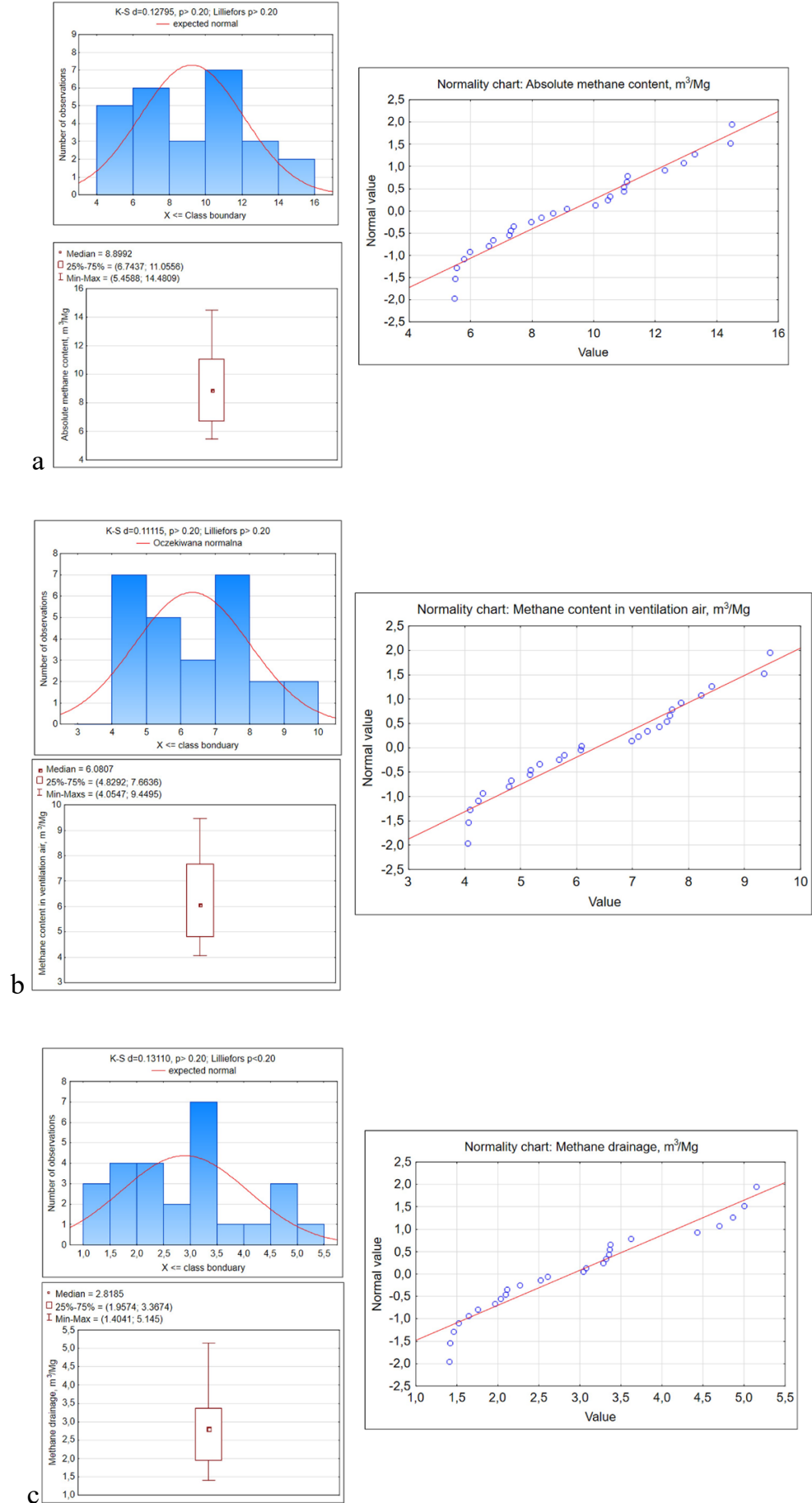

Fig. 3. Distributions of the values calculated per tonne of coal extracted for the variables under analysis (a-absolute methane content, b-methane content in ventilation air, $\mathrm{c}$ - methane drainage). 


\section{Conclusion}

Methane, which is released in increasing quantities during mining exploitation, is a very controversial gas. One the one hand, its flammability and explosiveness make it extremely dangerous; on the other, it is a valuable energy raw material. It is also one of the most dangerous greenhouse gases. Due to these features, it is necessary to carry out research and analyses to limit its negative impact on the process of mining production and the natural environment, and increase the utilisation of its energy potential.

The analysis results presented in the article reveal that, despite the recent decrease in coal production in Polish coal mines, the degree of methane emissions is still very high. This is particularly clear for one tonne of coal extracted. In 1994, there were $5.76 \mathrm{~m}^{3}$ of methane per tonne of coal extracted, whereas in 2018 - as much as $14.45 \mathrm{~m}^{3}$ of this gas, which is an over 2.5-fold increase. Undoubtedly, a positive phenomenon is the increased absolute quantity of methane captured via drainage systems over the analysis period from 212.8 million $\mathrm{m}^{3}$ (in 1994) to 317 million $\mathrm{m}^{3}$ (2018). Despite such a significant increase in the quantity of methane captured via drainage systems, its commercial use increased only

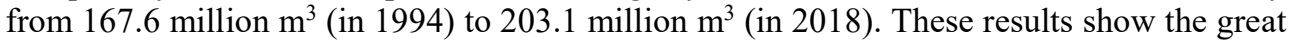
potential lying in the economic use of methane.

The amounts of methane emitted into the natural environment are also highly disadvantageous. As a result, the opinion about the mining industry in the context of the European climate policy is very unfavourable.

The analyses and their results demonstrate the significant problem caused by methane in the process of mining production. It seems that limiting its negative impact requires a very dynamic development of methane drainage systems. The methane obtained from these systems must be fully utilised on a commercial basis. Such an approach will make it possible to limit the methane hazard and obtain additional funds by Polish mines.

\section{References}

1. D. Szurgacz, L. Sobik, J. Brodny, E3S Web Conf., 105, 01013 (2019)

2. W. Dziurzyński, E. Krause, Arch. Min. Sci., 57(4), 819-830 (2012)

3. E. Krause, Arch. Min. Sci., 60(2), 581-594 (2015)

4. M. Tutak, J. Brodny, Energies, 12(20), 3840 (2019)

5. J. Brodny, M. Tutak, A. John, Mechanika 24(5), 695-702 (2018)

6. J. Brodny, M. Tutak, Arch. Control Sci., 29(1), 25-39; (2019)

7. M. Tutak, J. Brodny, Energies 12(20), 3840 (2019)

8. M. Tutak, J. Brodny, Int. J. Environ. Res. Public Health 16(8), 1406 (2019)

9. M. Tutak, J. Brodny, IOP Conf. Ser. Earth Environ. Sci., 95, 042025 (2017)

10. M. Tutak, J. Brodny, IOP Conf. Ser. Earth Environ. Sci., 95, 042026 (2017)

11. P. Małkowski, Ł. Ostrowski, J. Brodny, J. Sustain. Min. 17(3), 145-157 (2018)

12. D. Szurgacz, J. Brodny, E3S Web Conf., 29, 00006; (2018)

13. D. Szurgacz, J. Brodny, Energies, 13(2), 405 (2020)

14. K. Warmuzinski, Process Saf. Environ., 86, 315-320 (2008)

15. S. Kędzior, Int. J. C. Geol., 80, 20-34 (2009)

16. R. Patyńska, The Bulletin of The Mineral and Energy Economy Research Institute of the Polish Academy of Sciences, 86, 151-165 (2014) 
17. P. Balcombe, J.F. Speirs, N.P. Brandon, A.D. Hawkes,. Sci. Process. Impacts 20, $1323-1339 ;(2018)$

18. J. Kabiesz, Raport roczny o stanie podstawowych zagrożeń naturalnych $i$ technicznych $w$ górnictwie węgla kamiennego (PGHD, Katowice, 2019)

19. J. Brodny, M. Tutak, J. Appl. Fluid Mech. 11(3), 545-553; (2018).

20. M. Tutak, J. Brodny, Appl. Sci. 9(24), 531 (2019)

21. J. Brodny, M. Tutak, Energies, 12(13), 2505 (2019)

22. WUG., URL: http://www.wug.gov.pl/bhp/stan_bhp_w_gornictwie 